\title{
右下顎枝部にみられた粘液線䊒腫の１例
}

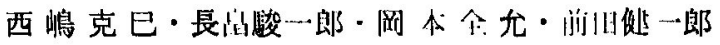

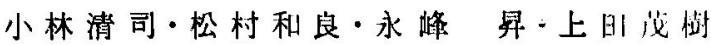

\section{A case of myxofibroma in the area of the right mandible ramus}

Katsumi Nishijima - Shunichiro Nagahata - Yoshimitsu Okamoto - Kinichiro Maeda

Seishi Kobayashi - Kazuyoshi Matsumura - Noboru Nagamine - Shigeki Ueda

\section{腥}

\section{흠}

粘㬵線維腫は，口腔領域において比較的まれな腫㻛で あり、注とんどが影骨に発生し顥骨中心性のものと口空 粘膜，歯槽部などの辺縁性のむのとに大別されている。 最近われわれは34藏女性の右下顎枝部に発生した部位的 にきわめてまれと思われる粘液線䊒尰の 1 例を経験した のて報告する。

\section{症例}

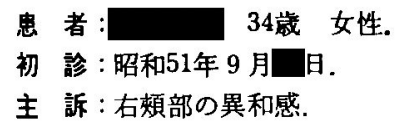

現病歴：約 1 か月前， $\underline{6}$ |の5蝕治療のため某菓科受 診の際，右下顎枝部の異常を指摘され当科受診.

\section{現 症}

全身所見：体格，栄養ともに中等度であり，全身的に は特に異常所見はみられなかった。顔貌は対称で, 左右 頻下リンパ節の腫脹，压痛は誌められなかった（写直 1).

口腔内所見 : $\overline{7}$ 遠心側に睡脹，王痛などの異常所見 は認められず, $\overline{8 \mid 8}$ は欠如，古|は拔崡を受けていた（写 真 2).

$\mathbf{X}$ 線所見：右下顎枝中央部に，くるみ大の境界明膫な 多房形成のX線透過像を認めた（写直 3-a， b).

臨床検查所見：血夜, 化学, 尿検査などたいて異常 所見は認められなかった。

処贯および程過：「エナメル上皮腫の疑い」の組織診

岡山大学医学部口腔外科学教室（主任：西嶋克已教

投)

Department of Oral Surgery, Okayama University Medical School (Chief: Prof. Katsumi Nishijima) 受付日: 昭和 53 年 8 月 7 日

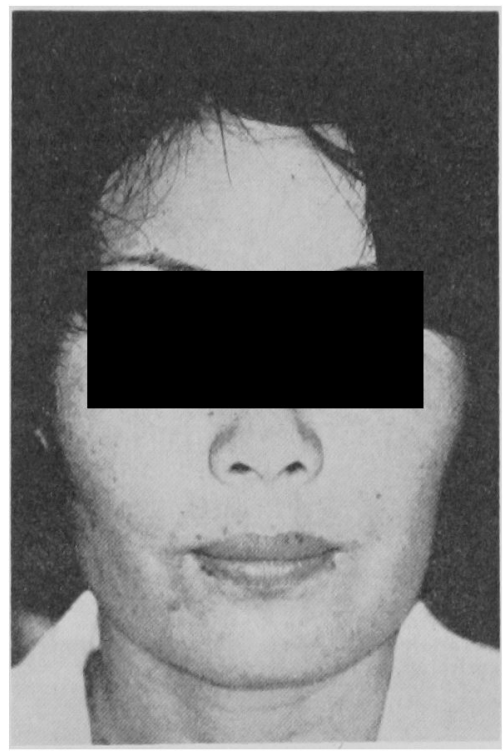

写重 1 顔貌写真

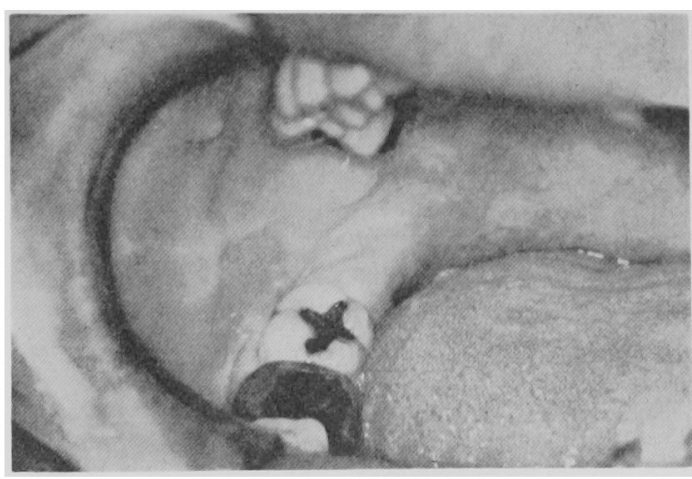

写真 2 口腔内所見

断のむと滑面板装着後 G-O-F 全身麻酔下で，可部啳 方より下顥枝片側離断を行い, 術後経過良好で現在再発 㑯向はみられない。 


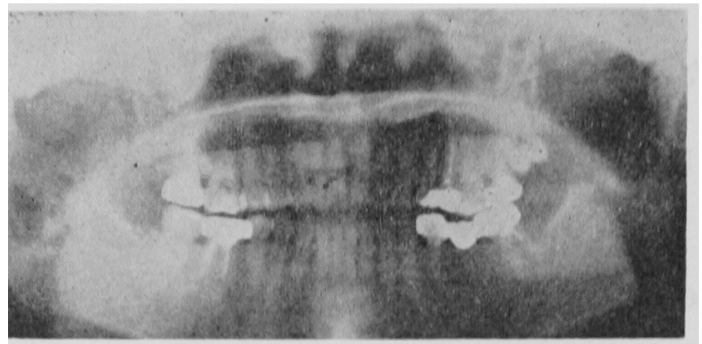

军 3-a オルンハントモグラム

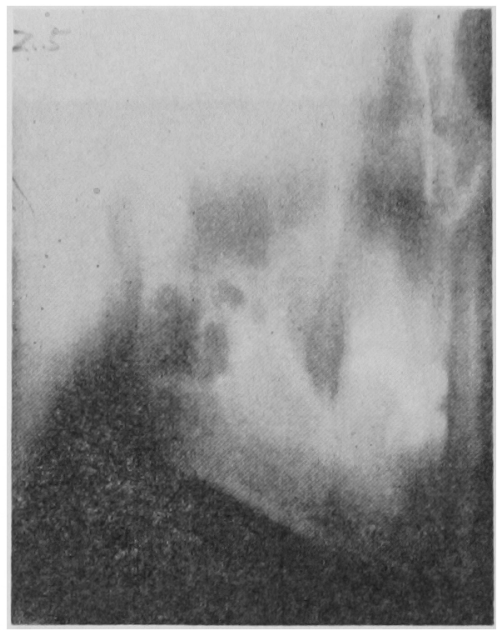

写重 3-b 䉼啳写真 $(2.5 \mathrm{~cm})$

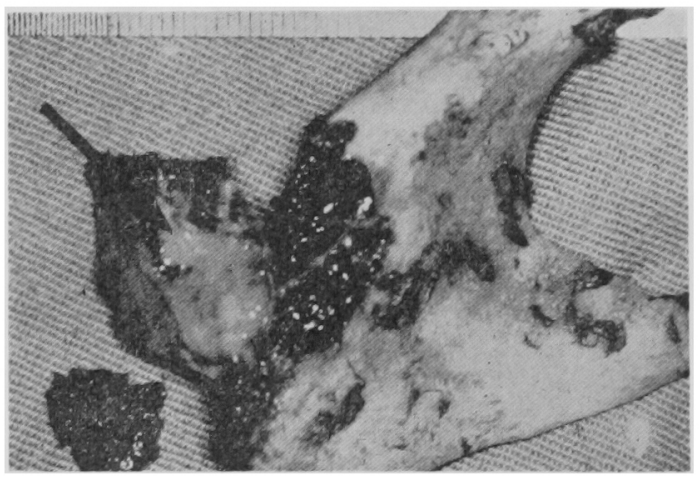

写颉 4 摘出物所見

摘出物所見：下買伎外側に骨の膨隆を恋め，骨質は菲 薄となり，内側中央部には直径約 $5 \mathrm{~mm}$ の骨吸収が られた，骨断面部は灰白色，ゼりー状であった（写真 4. 5).

病理組織学的所見：星状または紡鍾状の細長い異形成 を示さない細胞が、粘液様または浮隀性の基質中に存在 し，賿原線維を伴い柵状配列を呈していた（写真 6-a，

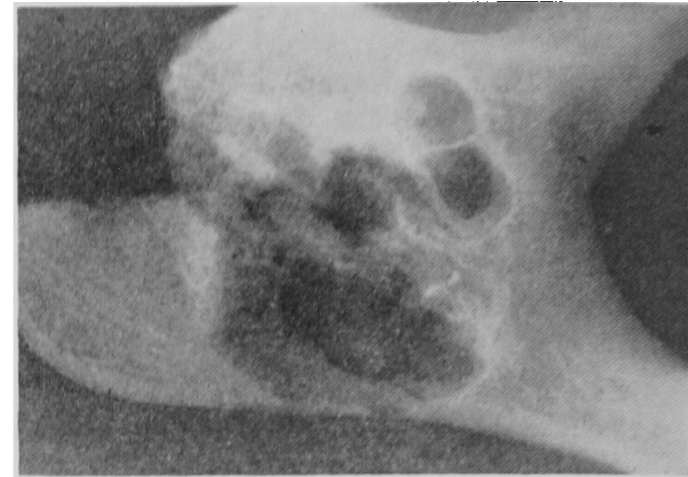

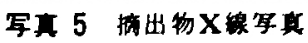

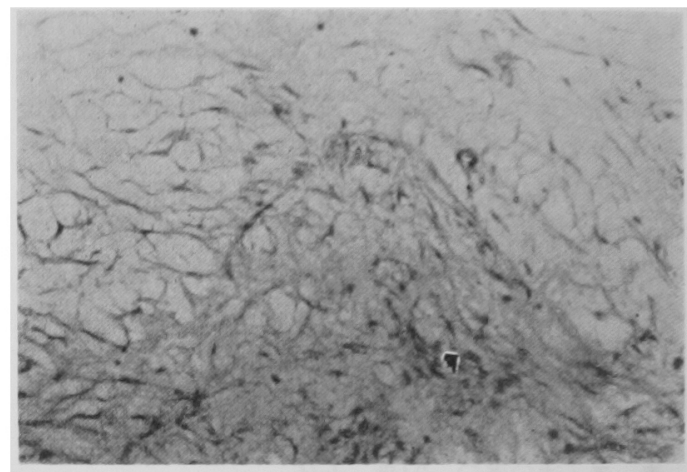

写亲 6-a 摘出物の病理組裁(H-E 染色, $\times 100$ )

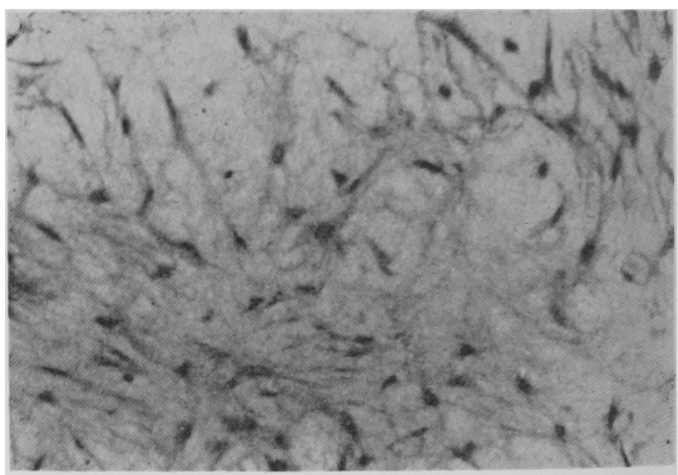

写并 6-b 摘出物の病理組像 (AB-PAS 染色, $\times 200)$

b).

診 断：以上の所見より粘夜線維腫と診断した。

考察

粘液線維腫は，おすに顎骨に発生する比較的まれな腫 㵧である. Zimmerman and Dahlin (1958) ${ }^{1)}$ は Mayo 


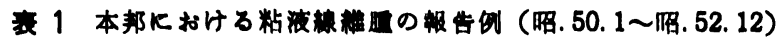

\begin{tabular}{|c|c|c|c|c|c|c|c|c|}
\hline 症冽 & 発㐬者名 & 年踰 & 性别 & 発生部位 & 大きさ & $\begin{array}{l}\text { 来院まての } \\
\text { 期间 }\end{array}$ & 症 状 & 如 住 \\
\hline 1 & 茂木敏雄, 他 ${ }^{6)}$ & 49 & \& & $\underline{7-2}$ 部 & $6 \times 4.5 \times 3 \mathrm{~cm}$ & 5 か月 & 無痛性腽服 & 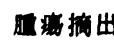 \\
\hline 2 & 茂木敏雄，他 ${ }^{5)}$ & 24 & ? & $\underline{7-3}$ 部 & $7 \times 5.5 \times 4.5 \mathrm{~cm}$ & 1 年 2 か月 & 焦痛性退服 & 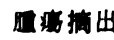 \\
\hline 3 & 玉井遠人，他 ${ }^{6)}$ & 49 & q & $\underline{6-4}$ 部 & 指㖩大 & 6 か月 & 無痛性回留 & 且的畝出 \\
\hline 4 & 玉井趡人，他 ${ }^{6)}$ & 24 & ? & $\underline{6-4}$ 部 & 小明大 & 6 か月 & 無犕性血服 & 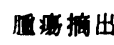 \\
\hline 5 & 新井 光, 他 ${ }^{7}$ & 38 & $\delta$ & 6 部 & 不 明 & 2 年 & 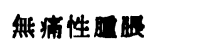 & 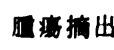 \\
\hline 6 & 辻 和穹, 他 ${ }^{8)}$ & 12 & q & $\overline{5-2} \mid$ 部 & 拇指賏大 & 4 か月 & 無瘄性目服 & 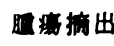 \\
\hline 7 & 伊東阹利，他 ${ }^{9)}$ & 45 & $\delta$ & $\overline{6-3}$ 部 & 小指㑔大 & 10か月 & 有痽性运服 & $\begin{array}{l}\text { 右下㖵 } \\
\text { 部分切除 }\end{array}$ \\
\hline 8 & 碳野和痁，他 ${ }^{10)}$ & 不明 & ô & 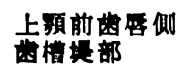 & 拇指㑔大 & 不 明 & 胍沕 & 股经揞出 \\
\hline 9 & 酒井康友，他 ${ }^{11)}$ & 28 & o & $\overline{375}$ 部 & 不 明 & 不 明 & 32 部眼隆 & 不 \\
\hline 10 & 酒井康友，他 ${ }^{11)}$ & 37 & $\delta$ & 口盖軟租就 & 不 明 & 不 明 & 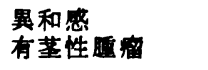 & 不 \\
\hline 11 & 酒井康友，他 ${ }^{11)}$ & 35 & $q$ & 7 部 & 䍌 卵 大 & 不 明 & 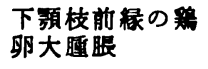 & 不 \\
\hline 12 & 酒井康友, 他 ${ }^{11)}$ & 38 & q & $\overline{8-5}$ 部 & 不 明 & 不 明 & $\overline{8-5}$ 部遁脹 & 不 \\
\hline 13 & 酒井庭友，他 ${ }^{11)}$ & 44 & $\delta$ & $\sqrt{6}$ 部 & 新 卵大 & 不 明 & 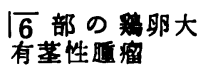 & 不 \\
\hline 14 & 酒井康友，他 ${ }^{11)}$ & 44 & 8 & $\underline{7-4}$ 部 & 不 明 & 不 明 & 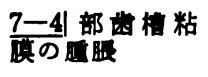 & 不 \\
\hline 15 & 酒井康友，他 ${ }^{11)}$ & 27 & $q$ & 61 部 & 不 明 & 不 明 & 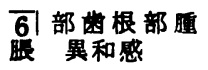 & 不 \\
\hline 16 & 酒井康友，他 ${ }^{11)}$ & 43 & 운 & $\overline{7-5}$ 部 & 不 明 & 不 明 & $\begin{array}{l}\overline{7-5} \text { 部近昆 } \\
7-5 \mid \\
\text { 部の動掘 }\end{array}$ & 不 \\
\hline $17^{\prime}$ & 長谷川 明, 他 ${ }^{12)}$ & 32 & ô & 右下影目部 & 不 明 & 不 明 & 不 明 & 運疰摘出 \\
\hline 18 & 井原邦夫, 他 ${ }^{13)}$ & 35 & q & $3-7$ 部 & 到 卵 大 & 7 か月 & 無痛性燠脹 & 尰饬摘出 \\
\hline 19 & 西鳰克巳, 他) & 26 & ㅇ & $\overline{475}$ 部 & $4 \times 3 \times 3 \mathrm{~cm}$ & 8 か月 & 無痛性遁脹 & 遁湯摘出 \\
\hline 20 & 本 症 例 & 34 & 9 & 右下影枝部 & くるみ大 & 1 か月 & 右煩部の異和感 & $\begin{array}{l}\text { 下影枝片 } \\
\text { 側漓断 }\end{array}$ \\
\hline
\end{tabular}

Clinic で50年間に26例，鈴木 $(1959)^{2)}$ は約 25 年間に13 例, 石川・秋吉 $(1973)^{3)}$ は約 30 年間に 20 例, 西嶋ら (1978)4) は昭和40年より昭和50年までの11年間に，本邦

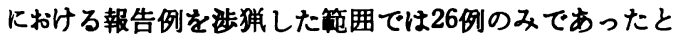
報告している。 またわれわれが昭和50年 1 月から昭和52 年12月までの 3 年間に，本邦における報告例を涉胖した 笛囲では19例みられた吕)(表 1).

本董湯の本態についての見解は種々述べられており，

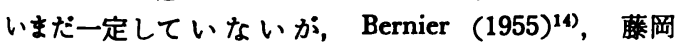
$(1960)^{15)}$ らは線䑾腫性組織が，粘液様変性に陥ったもの で，この場合の粘液腫と線維腫とは同一のものとしてい、 ろ. 鈴木 ${ }^{2)}$ は額骨粘夜腫は真の粘夜組織とは考えがたく 粘液様結合組織と考えるべきたとしている．また石川 $(1960)^{16)}$ は線䧽腫と本体的に同一のもので線䧽形成不能 のきわめて弱い幼若型であるとし, Stout $(1948)^{17)}$ は真 の遁湯と考えている.

発生由来に関して Thoma and Goldman (1947) ${ }^{18)}$ は 多くは覀性である骨原性のものと，より一般的で良性で
ある崡原性のものとに分類しているか，二者の爁別は非 常に困奞と思われる. しかし Zimmerman and Dahlin') は2,276 例の骨原発性尰㿣の5ち顔面骨以外に発生した 粘液腫はないとし, Stout ${ }^{17}$ は は骨粘液腫10例中 8 例が䫑 骨に発生したと報告，さらに鈴木2) は組織所見より雪原 性と考えている。 また Bruce and Royer (1952) ${ }^{19)}$ は |3 部に生じた例について 歯原性線維腫の変性によるる のとは考えにくいとし，増田ら (1971) 20)の骨原性と思 われる 2 例の報告すみられた。

発現年跲について Zimmerman and Dahlin') は10歳 以下，50歳以上はまれで10～29歳が67\%を占めていたと いい, 粐山ら $(1970)^{21)}$, 西嶋らは本邦における文献 的考察においてそれぞれ平均27.2歳，33.3歳で, 前者は 10歳台・20歳台で54.6\%，後者は20〜40藏台で76.9\%を 占めたと報告している．われわれが涉诵した19例におい ては平均36.9歳であり，30歳台が 7 例と多くみられた。 本症例は34歳であり，多いとされる年代であった。

性別頻度については, 鈴木 ${ }^{2}$, 石川・秋吉 ${ }^{3)}$, 粐山 


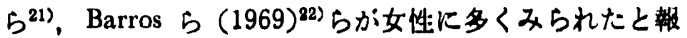
告しているよらに，われわれが涉晠した19例においてむ 女性12例と多くみられ，本症例も女性であった。

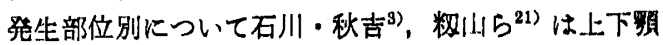
にはあまり盖がなかったと述へ，Barros ら²)，伊櫒ら

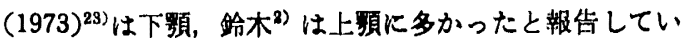
る。 また一般に好発部位は日造部である いわれているが，西䗷ら゙は啮狆した11年間では8 例が

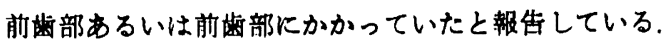
われわれが啮㷋した19例においては，下唄11例，上預8 例とやや下頪に多くみられ，目部のものは10例みられ た。しかし本症例のよらに下攧枝部にみられたものは西

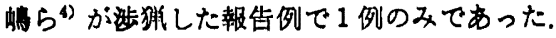

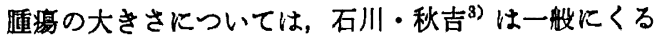
み大から然卵大に至る大きさのものがられたと述へ， 河本・森田 (1961) ${ }^{24)}$ は $12 \times 9 \times 8.8 \mathrm{~cm}$, Astaff $(1957)^{27}$, は10×10 cm とい5巨大な粘液線䊒腫を報告している。 本症例では，くるみ大であった。

患者が症状を自覚してから来院するまでの期間につ いては, Zimmerman and Dahlin ${ }^{1)}$ は平均 $1 \sim 3$ 年, Barros $5^{22)}$ は 1 週間から 15 年で平均 3 年と報告してい る. 本症例では，1か月と短期間に来院しているが、こ れはX線撮影による発見が早かったためであった。

X線所見では，石川・秋吉 ${ }^{3)}$, 茂木ら ${ }^{5)}$ は定型的なる ので滰界明瞙な多局性の透過像を示し，内部には樹枝 状の骨質を含む不透過像を示す。しかし Bruce and Royer ${ }^{19)}$ は典型的な X線所見はなかったと述へている。 本症例ではくるみ大の境界明眿な多房形成のX線像を示 し，摘出物のX線像ではやや樹枝状を示していた．また 增田 $5^{20)}$, 粐山 $5^{21)}$, Thoma and Goldman $(1960)^{28)}$ Бは fibroma, ameloblastoma, giant-cell reparative granuloma などとの鑑別診断は困難であると報告して いる.

処置および予後については，粐山ら ${ }^{21)}$ ， Barros ${ }^{22) ，}$ Feingold $(1957)^{29)}$ らは腫場組織の全摘出術を施行すれ ば予後は良好であったと報告している，われわれが啮椫 した19例においても畽瑒摘出10例と多くみられ，本症例 では骨破壊が強くみられたため下䝷枝片側離断を施行し 経過良好である。

\section{結}

論

われわれは，34歳女性の右下䪽枝部にみられた部位的 にきわめてまれと思われた粘液線䊒腫の 1 例および昭和 50 年 1 月より昭和 52 年 12 月までの本邦に打ける粘液線維 腫19例について文献的考察を行い，あわせて報告した。

稿を終わるに臨み, 岡山大学医学部第 2 病理学教室 大森正樹講師に深謝致します。なお本論文の要旨は,

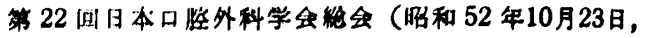

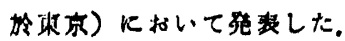

\section{引用文献}

1) Zimmerman, D.C. and Dahlin, D.C.: Myxomatous tumors of the jaws. OS OM OP 11: 10691958.

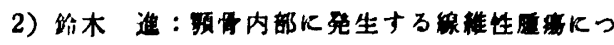

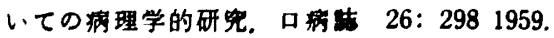

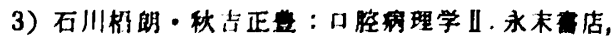
京都，1973，941面。

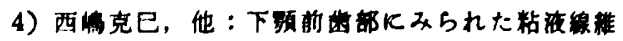
逼の1例。旦口外誌 24：941978.

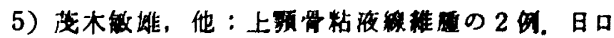
外部 21：612 1975 .

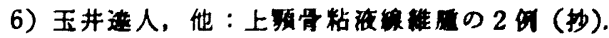
日口外誌 21：371 1975.

7）新井光, 他: 下影骨に発生した Myxo-Fibroma の 1 例(扬). 日外誌 21：856 1975.

8）辻和秀，他：下颖骨に甡生したMyxofibroma の1例（抄）。日外誌 21：857 1975.

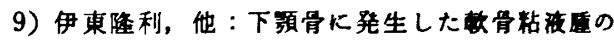
1 例 (抄)。口科誌 24: 2571975 .

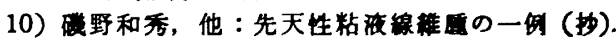
口科誌 24: 2571975.

11）酒井康友，他：口腔に発生した粘液線潵の 8 例. 柴科学報 76: 191976.

12）長谷川明，他：陪床的K Epulis を筷い，病 理組轼学的K Odongenic myxofibroma と考えら れる1例 (抄)。口科誌 25：186 1976.

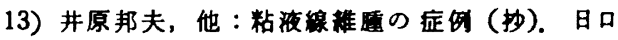
外詰 23: 9861977.

14) Bernier, J.L.: The management of oral disease. C.V. Mosby Co, St Louis, 1955, p 678.

15）藤岡幸雄：中心性領骨線椎原の種々相につい て. 口科誌 9:323 1960.

16）石川梧朗：齿原腫瓷について，とくに病理学的 方面から (その2). 口病誌 27: 3071960.

17) Stout, A.P.: Myxoma, the tumor of primitive mesenchyme. Ann Surg 127: 7061948.

18) Thoma, K.H. and Goldman, H.M.: Central myxoma of the mandible. Oral Surg 31: 465 1947.

19) Bruce, K.W. and Royer, R.Q.: Central fibromyxoma of the maxilla. OS OM OP 5: 12771952.

20）增田正樹, 他：中心性粘液楾椎隩の 2 例. 日口 外誌 17: 4321971 .

21）粐山正徳, 他: 額骨内粘液連の症例および本邦 におけるその文献的考察。口科誌 19: 957 1970.

22) Barros, R.E., et al.: Myxoma of the jaws. OS OM OP 27: 2251969. 
23）伊藤輝夫，他：下影に発生した odontogenic myxofibroma とその文嗝的考腺。日口外誌 19: 3651973.

24）河本健行・森田知生：下腬に発生した巨大ない わゆ万粘液線䑾腯の 1 例. 口外誌 7: 111961.

25）渡辺邦一，他：下额に笔生したいわゆる粘波線 耯血の 1 例. 口科誌 20:795 1971.

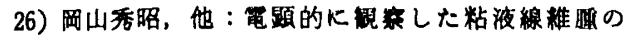

1 例。日口外此 19：491 1973.

27) Astaff, A.: Myxofibroma. OS OM OP 6: 2471957.

28) Thoma, K.H. and Goldman, H.N.: Oral Pathology. ed 5, Mosby Co, St Louis, 1960, p 1367.

29) Feingold, M.: Myxofibroma of the maxilla. OS OM OP 9: 8261957. 